\title{
PERSONAL HYGIENE REMAJA PUTRI KETIKA MENSTRUASI
}

\author{
FEMALE ADOLESCENTS PERSONAL HYGIENE DURING MENSTRUATION
}

\author{
Katarina Canggih Pythagoras \\ Departemen Promosi Kesehatan dan Ilmu Perilaku \\ Fakultas Kesehatan Masyarakat, Universitas Airlangga, Surabaya \\ Email: katarina.canggih.pythagoras-2015@fkm.unair.ac.id
}

\begin{abstract}
Adolescence is a transitional period from childhood to adulthood. In the transition, there are three stages that include growth process, development, and maturation of genital hormones, namely the primary and secondary change. Male and female adolescent also happen to experience these changes. However, the female adolescents are in a higher risk for having reproductive tract infection. The continuous reproductive tract infection can result in infertility until pregnancy occurs outside the womb. The causes of reproductive tract infection vary, such as improper personal hygiene behavior. Such behavior includes replacing sanitary napkin less than four times in a day, using inappropriate pad material, often using antiseptics to treat genital, not replacing underwear twice a day, not changing sanitary napkin for each 1-hour to 2-hour usage in the first day of menstruation, and not replacing sanitary napkin after urinating, defecate, and bathing. The study aims at describing the behavior of female adolescents about personal hygiene during menstruation in SMPN 2 Kras, Kediri district. The study uses descriptive research design. The population of the study is female adolescents at class VII and VIII with the total of 191 students. The study collects data from 130 respondents by using Simple Random Sampling. The result of general behavior of female adolescents personal hygiene during menstruation shows 47 percents already meet the criteria, while 26 percents sufficiently meet the criteria, and 27 percents do not meet the criteria. It is suggested that school collaborates with local area health institutions in providing basic activities to overcome such health problem. These activities can be done through communication, information and education (IEC) along with the distribution of poster and leaflet about reproductive health especially personal hygiene during menstruation.
\end{abstract}

Keywords: female adolescents behavior, personal hygiene menstruation

\begin{abstract}
Abstrak: Masa remaja merupakan masa peralihan dari anak menuju dewasa. Di dalam proses transisi terdapat tahap pertumbuhan, perkembangan serta kematangan hormon pada organ genetalia, yaitu terjadi perubahan primer dan sekunder. Perubahan tidak hanya dijalani oleh remaja putra, melainkan remaja putri juga. Remaja putri termasuk kategori kelompok yang lebih berisiko tinggi terkena Infeksi Saluran Reproduksi (ISR). ISR yang berlanjut dapat mengakibatkan kemandulan hingga terjadi kehamilan di luar kandungan. Penyebab ISR beragam, salah satunya adalah perilaku personal hygiene yang tidak benar. Perilaku tersebut meliputi mengganti pembalut kurang dari 4 kali dalam sehari, bahan pembalut yang digunakan tidak tepat, sering menggunakan antiseptik guna merawat genetalia, tidak mengganti celana dalam kurang 2 kali sehari, mengganti pembalut tidak 1-2 jam ketika hari pertama menstruasi, cara cebok yang salah, sesudah Buang Air Kecil (BAK), Buang Air Besar (BAB) dan mandi tidak mengganti pembalut. Penelitian ini bertujuan untuk menggambarkan perilaku remaja putri mengenai personal hygiene saat menstruasi. Penelitian ini menggunakan rancang bangun deskriptif. Populasi penelitian adalah 191 orang, kelas VII dan VIII di SMPN 2 Kras Kabupaten Kediri. Sampel sejumlah 130 orang dengan teknik simple random sampling. Hasil penelitian menunjukkan bahwa perilaku remaja putri tentang personal hygiene saat menstruasi dalam komponen kognitif berkriteria baik adalah 47 persen, komponen afektif berkriteria baik sebanyak 26 persen, dan komponen konatif berkategori kurang sejumlah 27 persen. Berdasarkan hasil tersebut, saran atas penelitian adalah melakukan kerja sama lintas sektor secara aktif. Bentuk kerja sama yang diharapkan adalah melaksanakan kegiatan sosialisasi seperti komunikasi, informasi, dan edukasi (KIE) disertai dengan pemberian poster maupun leaflet terkait kesehatan reproduksi pada remaja putri terutama personal hygiene saat menstruasi.
\end{abstract}

Kata kunci: perilaku remaja putri, personal hygiene ketika menstruasi 


\section{PENDAHULUAN}

Masa remaja berawal saat usia 12 sampai dengan 24 tahun (WHO). Peraturan Menteri Kesehatan RI Nomor 25 Tahun 2014 menjelaskan remaja adalah penduduk dalam rentang usia 10-18 tahun. Sedangkan menurut BKKBN, 10-24 tahun tergolong usia remaja dengan status belum melakukan pernikahan. Remaja akan melalui banyak peristiwa dalam tahap perkembangan dan pertumbuhan. Adapun peristiwa tersebut yaitu munculnya beberapa ciri alat kelamin sekunder meliputi tumbuh suburnya rambut pada area kewanitaan dan bulu ketiak, lingkar pinggul melebar, mengalami menstruasi, mengencangnya ukuran payudara, kulit kian terasa halus, dan lebih emosional. Seorang remaja putri akan menstruasi apabila sistem reproduksi dan berbagai komponen hormon yang berada di tubuh telah prima. Proverawati (2009) menegaskan, haid merupakan perdarahan di uterus terjadi secara berangsur dan teratur. Selain itu, dapat dibarengi dengan adanya proses pelepasan pada endometrium. Menstruasi yang terjadi bersamaan dengan fase ovulasi sebagian besar terjadi sekitar usia 17 hingga 18 tahun. Manuaba (2009) mengungkapkan bahwa menstruasi yang terjadi dikatakan normal dengan rentang antara 26 sampai 32 hari. Berdasar dua argumentasi diatas, dapat ditarik kesimpulan bahwa menstruasi ialah keluarnya darah di uterus yang lumrah dialami oleh perempuan setiap bulan dan dibarengi proses peluruhan pada dinding rahim.

Remaja putri rentan terkena infeksi organ reproduksi. Hal ini terjadi karena kurangnya perilaku dalam merawat kebersihan diri terutama saat mengalami menstruasi. Remaja putri memiliki tingkat perhatian yang rendah terkait kesehatan reproduksi. Menurut hasil dari penelitian yang telah dilakukan oleh Wulandari tahun 2012, didapatkan bahwa pengetahuan yang diterima oleh remaja putri berusia 13 hingga 16 tahun tentang perawatan alat reproduksi eksternal ketika menstruasi sebagian besar adalah cukup, yaitu 63 persen. Selain itu, perilaku dalam melakukan perawatan terhadap organ reproduksi eksternal yang mayoritas dalam frekuensi cukup sejumlah 48 persen. Permasalahan ini disebabkan oleh pendidikan yang tergolong rendah dan memiliki usia yang relatif muda diasumsikan tidak memiliki faktor pemungkin untuk terkena suatu penyakit yang dapat menyerang organ reproduksi (Sari, 2012). Sementara itu, Lely tahun 2012 mengungkapkan peningkatan kejadian infeksi pada organ reproduksi dapat dipengaruhi oleh zaman globalisasi diwujudkan dengan lebatnya aliran informasi yang deras dan cepat.

Berdasarkan data yang dihimpun dari Badan Pusat Statistik dan Badan Perencanaan Pembangunan Nasional pada tahun 2010, 63 juta remaja di Negara Indonesia berisiko melakukan perilaku yang tidak sehat. Misal, kurangnya tindakan merawat kebersihan organ reproduksi ketika mengalami menstruasi. Angka insiden penyakit infeksi yang terjadi pada saluran reproduksi pada remaja (10-18 tahun), yaitu 35 sampai 42 persen serta dewasa muda (18-22 tahun) sebesar 27 hingga 33 persen. Rahmatika (2010) dalam penelitiannya mengungkapkan bahwa faktor pemicu kasus ISR antara lain imunitas yang rendah sejumlah 10 persen, perilaku kurang dalam merawat hygiene ketika menstruasi sejumlah 30 persen, lingkungan buruk dan tata cara dalam penggunaan pembalut yang kurang tepat ketika menstruasi sejumlah 50 persen. Pemaparan tersebut juga diperkuat dari hasil penelitian yang dilakukan oleh Ariyani tahun 2009 terkait dengan biopsikososial hygiene saat menstruasi pada siswi SMP di ibukota Jakarta menekankan bahwa remaja putri yang mempunyai perilaku baik dalam perawatan hygiene genetalia ketika mendapati dirinya menstruasi hanya 17,4 persen. Sisanya, yaitu sejumlah 82,6 persen memiliki perilaku yang kurang dalam menjaga kebersihan alat genetalia ketika menstruasi.

Pengetahuan yang diberikan memiliki tujuan, yaitu penambahan informasi mengenai menstruasi. Materi tersebut, perlu diutarakan kepada kelompok remaja putri. Sukarni tahun 2013, menjelaskan pengetahuan terkait menstruasi sangat dibutuhkan oleh para remaja putri. Konsekuensi yang muncul dari rendahnya pengetahuan ialah kurang mendapatkan informasi terkait personal hygiene terutama 
pada saat mengalami menstruasi. Tingkat pendidikan orang tua yang rendah dan kurangnya pengetahuan remaja tentang menstruasi sering dikira bahwa kesehatan pada reproduksi merupakan suatu perbincangan paling tabu untuk diulas dengan detail dan mendalam. Pernyataan ini dipertegas oleh penelitian Kurniawati, dkk (2012) bahwa orang tua sangat sentimen dalam membahas reproduksi kepada anaknya. Kesehatan reproduksi dianggap tidak layak untuk dilontarkan karena terkait rahasia setiap individu dan masingmasing individu merasa tidak nyaman apabila disuruh membahas hal tersebut. Pendidikan kesehatan seputar reproduksi semestinya sudah diberikan kepada seorang remaja, bahkan harus disampaikan sedini mungkin. Hal ini dilakukan karena informasi yang telah diperoleh sejak kecil, kelak akan bermanfaat untuk disimpan dan dipergunakan sebagai suatu bekal saat dewasa nanti.

Pendidikan mengenai kesehatan terutama sistem reproduksi, sangat perlu untuk diperhatikan oleh segenap kalangan, termasuk para orang tua maupun remaja itu sendiri. Manuaba tahun 2009, menyatakan bahwa infeksi yang terjadi pada organ direproduksi dapat mengakibatkan infertile (kemandulan) dan meningkatkan angka kejadian kehamilan ektopik terganggu atau kehamilan yang berada di luar kandungan. Oleh karena adanya penyakit tersebut, orang tua mempunyai andil yang besar guna menanamkan pemahaman terkait kesehatan pada reproduksi terhadap anak. Remaja putri pun demikian, tentunya lebih berterus terang pada orang tua mengenai permasalahan kesehatan organ reproduksi, bertanya pada orang tua atau guru sekolah jika mengalami kejadian yang membuat tidak nyaman menghadapi menstruasi beserta upaya untuk menanggulangi ketidaknyamanan tersebut. Komunikasi efektif antara orang tua dan anak merupakan suatu proses penyampaian informasi yang dilandasi oleh sikap saling percaya, terbuka, dan berbagai dukungan positif (Rakhmat, 2013). Dengan adanya sikap tersebut, maka diharapkan dapat mengurangi berbagai keluhan yang dihadapi remaja.
Pengetahuan remaja putri yang dinilai baik akan mempengaruhi sikap hingga bentuk perilaku untuk berusaha menjaga kebersihan genetalia. Perilaku memiliki pengertian, yaitu sebuah respons untuk melakukan suatu tindakan tertentu. Perilaku secara terstruktur dibagi menjadi tiga aspek antara lain aspek kognitif atau pengetahuan, aspek afektif atau sikap, dan aspek konatif atau tindakan. Wawan dan Dewi (2011), aspek kognitif atau pengetahuan ialah sebuah kepercayaan yang ada dalam diri seorang individu atau keyakinan yang dimiliki oleh satu orang mengenai suatu hal yang dapat mengangkat berita tertentu. Notoatmodjo tahun 2010 menjelaskan bahwa aspek afektif atau sikap merupakan suatu komponen yang emosional tentang sebuah pemberian nilai terkait peristiwa yang diketahui oleh manusia. Aspek konatif atau penatalaksanaan merupakan elemen yang merangkum suatu kecenderungan untuk melakukan sebuah tindakan. Berdasar ulasan tersebut, dapat diketahui bahwa ketiga aspek diatas saling berikatan satu dengan yang lain.

Faktor determinan yang dapat menimbulkan sebuah perilaku, yaitu faktor internal dan eksternal. Pertama, faktor internal mencakup banyaknya pengetahuan yang diperoleh, tingkat kecerdasan individu, persepsi yang ada dalam benak setiap manusia, tekanan emosi seseorang, dan motivasi untuk mencapai keinginan tertentu. Kedua, faktor eksternal meliputi lingkungan yang berada di sekitar kita, melingkupi lingkungan fisik maupun non fisik seperti suhu udara setempat, iklim yang sedang terjadi, keadaan dan kondisi sosial ekonomi masyarakat, dan kebudayaan yang dianut warga sejak dahulu (Notoatmodjo, 2011). Jadi, dari dua faktor tersebut, dapat lebih dipertegas bahwa perilaku akan dapat mengalami perubahan baik langsung dan tidak langsung. Hal ini juga akan memengaruhi perilaku dalam menjaga kesehatan termasuk personal hygiene.

Asal kata personal hygiene dari bahasa Yunani, personal mempunyai arti individu atau seseorang dan hygiene memiliki makna bersih atau sehat (Mubarak dan Chayaning, 2008). Maksud dari dua kata tersebut 
adalah usaha dari setiap manusia yang wajib dilakukan dalam keseharian guna terpeliharanya kebersihan serta kesehatan diri, terkait secara fisik maupun psikologis. Dengan demikian, perawatan terhadap tubuh harus dibiasakan minimal dengan mandi dua kali dalam sehari. Menjaga kesehatan perineal juga penting terlebih ketika menstruasi. Hal ini perlu karena pada saat menstruasi, kuman dan bakteri mudah masuk dan dapat menginfeksi organ vital perempuan.

Studi pendahuluan yang dilakukan diSMPN 2 Kras, diperoleh hasil bahwa remaja putri kelas VII dan VIII belum pernah mendapatkan paparan informasi berupa penyuluhan mengenai personal hygiene saat menstruasi. Selain hal itu, ternyata perpustakaan belum mempunyai buku bacaan terkait personal hygiene saat menstruasi dan tidak terdapat leaflet maupun poster mengenai kesehatan reproduksi remaja.

Berdasarkan pemaparan diatas, maka bermaksud melakukan penelitian lebih mendetail mengenai perilaku pada remaja putri tentang personal hygiene ketika menstruasi. Adapun tujuan umum dari penelitian ini adalah mengidentifikasi gambaran perilaku remaja putri tentang personal hygiene ketika menstruasi. Sedangkan, tujuan khusus dari penelitian ini ialah mengidentifikasi perilaku dari remaja putri mengenai personal hygiene pada saat menstruasi di komponen kognitif atau pengetahuan, mengidentifikasi perilaku pada remaja putri terkait personal hygiene ketika menstruasi di aspek afektif atau sikap, dan mengidentifikasi perilaku remaja putri tentang personal hygiene ketika mengalami menstruasi di tingkatan konatif atau tindakan.

\section{METODE}

Desain penelitian menggunakan deskriptif dengan menggambarkan perilaku pada remaja putri terkait personal hygiene ketika menstruasi. Populasi yang digunakan adalah seluruh remaja putri kelas VII dan
VIII sejumlah 191 orang. Setelah dihitung dengan rumus, diperoleh sampel sebanyak 130 orang yang diambil dengan teknik simple random sampling.

Sumber data yang digunakan ialah data primer dan data sekunder. Data primer didapatkan dari penyebaran instrumen, observasi dan wawancara. Data sekunder diperoleh dari jurnal ilmiah, buku, artikel pada skripsi, badan pemerintah terkait kesehatan, dan sebagainya.

Remaja putri di SMPN 2 Kras, Kabupaten Kediri kelas VII dan VIII yang telah mengalami menstruasi dan siap sedia berkenan ikut serta secara aktif dalam keberlangsungan proses pengambilan data dimasukkan dalam kriteria inklusi.

Responden yang terlibat penelitian mendapatkan informed consent atau lembar persetujuan. Apabila seorang subjek penelitian bersedia untuk diteliti, maka diharuskan untuk menandatangani. Dalam kuesioner terdapat anonymity atau tanpa nama, yang dapat diartikan bahwa hanya memberikan sebuah nomor di setiap lembar. Selain itu, confidentiality tau kerahasiaan, yaitu peneliti memberikan jaminan kepada seluruh responden terkait pengisian jawaban. Data yang telah didapatkan oleh peneliti, dikumpulkan dan dijadikan satu. Data tersebut kemudian diolah mulai dari proses editing, memberikan coding pada setiap lembar, melakukan scoring, dan memasukkan data dalam tabulating yang selanjutnya dilakukan analisis secara komprehensif sehingga diperoleh data valid.

\section{HASIL PENELITIAN}

Karakteristik dalam kategori usia diketahui bahwa mayoritas responden 14 tahun. Hal ini dikarenakan pada usia tersebut remaja putri telah mengalami menstruasi. Selain itu, kategori pada usia pertama kali mendapati menstruasi, lebih dari 50 persen responden mengalami pada usia 12 tahun. Diketahui pula, rentang jarak antara usia sekarang dan usia pertama kali responden mengalami siklus menstruasi sejumlah 59 orang, yaitu 2 tahun. 
Tabel 1. Karakteristik Subjek Penelitian Berdasarkan Usia, Usia Pertama Kali Mengalami Menstruasi serta Rentang Jarak dari Usia Sekarang dan Usia Pertama Kali Menstruasi, dan di SMPN 2 Kras, Kabupaten Kediri

\begin{tabular}{lcc}
\hline Karakteristik & Frekuensi & $\mathbf{\%}$ \\
\hline Usia & 4 & 3,07 \\
12 & 51 & 39,2 \\
13 & 64 & 49,2 \\
14 & 9 & 7,0 \\
15 & 2 & 1,53 \\
16 & $\mathbf{1 3 0}$ & $\mathbf{1 0 0}$ \\
\hline Total & 1 & \\
\hline Usia Pertama Kali Menstruasi & 0,8 \\
10 & 12 & 9,23 \\
11 & 70 & 53,8 \\
12 & 42 & 32,3 \\
13 & 4 & 3,07 \\
14 & 1 & 0,8 \\
\hline 15 & $\mathbf{1 3 0}$ & $\mathbf{1 0 0}$ \\
\hline Total & & \\
\hline Rentang Jarak Usia Sekarang dan Usia \\
Pertama Kali Menstruasi & \\
0 & 0 & 7,0 \\
1 & 50 & 38,4 \\
2 & 59 & 45,3 \\
3 & 12 & 9,3 \\
\hline Total & $\mathbf{1 3 0}$ & $\mathbf{1 0 0}$ \\
\hline
\end{tabular}

Tabel 2. Karakteristik Subjek Penelitian Berdasarkan Sumber Informasi Memperoleh Pengetahuan tentang Personal Hygiene saat Menstruasi di SMPN 2 Kras, Kabupaten Kediri

\begin{tabular}{lcc}
\hline Sumber Informasi & Frekuensi & $\mathbf{\%}$ \\
\hline Orang tua & 70 & 53,8 \\
Guru & 4 & 3,1 \\
TV dan majalah & 4 & 3,1 \\
Teman & 52 & 40 \\
\hline Total & $\mathbf{1 3 0}$ & $\mathbf{1 0 0}$ \\
\hline
\end{tabular}

Pada Tabel 2, dapat dilihat bahwa sebagian besar responden mendapatkan informasi mengenai pengetahuan kesehatan reproduksi dari orang tua. Orang tua terutama Ibu memiliki peran untuk dapat memberikan ilmu pengetahuan mengenai kesehatan reproduksi pada anak.

Tabel 3 menunjukkan bahwa perilaku dalam aspek kognitif atau pengetahuan pada
Tabel 3. Distribusi Perilaku dalam Komponen Kognitif atau Pengetahuan mengenai Personal Hygiene ketika Menstruasi di SMPN 2 Kras, Kabupaten Kediri

\begin{tabular}{lcr}
\hline \multicolumn{1}{c}{ Kriteria } & Frekuensi & $(\mathbf{( \% )}$ \\
\hline Baik & 130 & 100 \\
Cukup & 0 & 0 \\
Kurang & 0 & 0 \\
\hline Total & $\mathbf{1 3 0}$ & $\mathbf{1 0 0}$ \\
\hline
\end{tabular}

remaja putri secara menyeluruh ialah baik. Tabel 1 menjelaskan, dua tahun merupakan rentang jarak pada usia sekarang dan usia saat menstruasi yang pertama kali. Responden memiliki pengetahuan baik karena telah mengalami menarche atau usia pertama kali menstruasi lebih dini dan sudah mendapatkan informasi terkait personal hygiene saat menstruasi yang memadai. Dengan adanya pengalaman dan penerimaan informasi yang efektif dan komprehensif, maka hal tersebut secara otomatis akan menambah wawasan responden mengenai personal hygiene menstruasi.

Pengalaman ialah suatu kegiatan yang dapat digunakan untuk membentuk pengetahuan seseorang dan dilaksanakan secara berulang kali akan memunculkan sebuah perilaku. Jadi, semakin awal remaja mengalami menstruasi pertama, maka semakin banyak peristiwa yang didapatkan oleh individu. Pengalaman yang baik tersebut pun dapat dikonstruksikan dengan adanya peningkatan tentang sebuah ilmu terkait pengetahuan. Dapat digarisbawahi bahwa pengalaman memiliki kontribusi yang cukup besar dalam meningkatkan pengetahuan dalam diri seseorang. Pernyataan tersebut senada dengan yang dijelaskan oleh Kamil dan Fuad Bahsin tahun 2008, pengalaman dapat memberikan sumbangsih berupa informasi dalam bentuk pengetahuan dan keahlian dalam pengambilan suatu keputusan yang dipergunakan untuk membantu proses menunjang nalar pikir secara ilmiah. Dengan adanya pengalaman maka kemampuan seseorang dalam upaya penambahan informasi guna menyelesaikan permasalahan yang dihadapi. Teori yang berhasil dikembangkan oleh Notoatmodjo tahun 2011 mengungkapkan pengalaman 
yang dialami oleh seseorang maupun penelitian yang dikerjakan oleh manusia dapat berpengaruh terhadap perilaku yang dilakukan oleh individu. Kedua hal tersebut, dilatarbelakangi oleh adanya pengetahuan yang memenuhi syarat dan munculnya perilaku yang memadai. Maka dapat ditarik kesimpulan, pengetahuan yang baik diwujudkan dengan perilaku yang juga baik. Pengetahuan yang memadai akan mendorong individu untuk melakukan sebuah perilaku yang sehat.

Tingkat pendidikan yang ditempuh berdampak terhadap penambahan ilmu pengetahuan yang dimiliki seseorang. Oleh sebab itu, kian mudah orang menerima dan membagikan informasi kepada orang lain sehingga semakin tinggi pula jenjang pendidikan yang dilakoni. Namun sebaliknya, apabila seseorang memiliki pendidikan yang rendah, maka pemahaman mengenai penjelasan informasi akan sulit untuk diingat dan diterima.

Pemberian informasi dari komunikator yang cerdas, akan berpengaruh baik dalam penambahan pengetahuan komunikan. Sumber sebuah informasi yang didapatkan oleh remaja sebagian besar diperoleh dari orang tua. Orang tua dalam hal ini memiliki andil yang cukup banyak untuk menyampaikan materi pembelajaran kepada anak terlebih mengenai kesehatan reproduksi khususnya personal hygiene ketika mengalami menstruasi. Penelitian ini memiliki kesesuaian dengan penelitian yang telah dilaksanakan oleh Rahmayanti tahun 2012, bahwa pengetahuan seseorang dapat diperoleh dari lingkungan sekitar tempat ia tinggal atau hidup. Lingkungan menyumbang beberapa informasi yang dapat mempertajam pola pikir, sehingga membuat remaja putri harus pandai dalam proses pengambilan keputusan tertentu. Berada di lingkungan yang mendukung, maka seseorang tidak akan mengalami kesulitan untuk beradaptasi sehingga orang tersebut dapat dengan mudah menyerap segala pesan yang tersirat maupun tersurat. Lingkungan adalah suatu bentuk dari dukungan sosial seperti teman dan keluarga termasuk orang tua. Bentuk dukungan sosial yang dimaksud salah satunya ialah melakukan interaksi, bersosialisasi satu sama lain dengan saling membagikan ilmu terkait berbagai hal terutama mengenai reproduksi yang sehat. Informasi merupakan salah satu dari faktor yang memiliki pengaruh pada seseorang secara langsung maupun tidak langsung. Kian mudah dan sering seseorang menerima serta terpapar oleh sebuah informasi yang didapatkan dari lingkungan terutama orang tua, maka akan kian banyak pula pengetahuan yang diperolehnya.

Perilaku dalam aspek afektif atau sikap responden adalah 38,5 persen baik. Pada komponen pengetahuan atau kognitif, secara keseluruhan atau sejumlah 130 orang, baik dalam pengetahuan tentang personal hygiene saat menstruasi. Pernyataan tersebut dapat digunakan sebagai dasar terbentuknya sikap yang baik pula dalam diri remaja putri. Responden banyak yang berpengetahuan baik karena lebih dini mengalami haid pertama kali. Remaja putri yang lebih awal mendapati menarche akan memperoleh pelajaran yang luas daripada responden yang baru saja mengalami. Keeratan sebuah pengalaman mempunyai hubungan terhadap strata pendidikan dan usia seseorang. Senada dengan Keraf (2011) bahwa pengalaman seseorang dipengaruhi oleh banyak hal. Hal tersebut meliputi tingkat pendidikan, kesehatan fisik dan usia seseorang. Tingginya strata dalam pendidikan yang berhasil dilewati, dapat memudahkan seseorang untuk mampu menerima beragam bentuk ilmu dan sekumpulan informasi sehingga pengalaman yang diperoleh juga semakin kaya. Kian menua umur seorang individu maka kian beraneka pula pengalaman hidup yang dimiliki sehingga pemahaman orang tersebut akan bertambah. Kejadian pertama kali mengalami menstruasi yang lebih awal dengan keterkaitan sikap

Tabel 4. Distribusi Perilaku Komponen Afektif atau Sikap Mengenai Personal Hygiene saat Menstruasi di SMPN 2 Kras, Kabupaten Kediri

\begin{tabular}{lcc}
\hline Kriteria & Frekuensi & $\mathbf{( \% )}$ \\
\hline Baik & 50 & 38,5 \\
Cukup & 46 & 35,3 \\
Kurang & 34 & 26,2 \\
\hline Total & $\mathbf{1 3 0}$ & $\mathbf{1 0 0}$ \\
\hline
\end{tabular}


baik ditunjukkan oleh subjek penelitian melalui data primer dalam penelitian bahwa sejumlah 59 remaja putri yang memiliki jarak antara usia sekarang dengan usia pertama kali menstruasi ialah 2 tahun. Dua tahun merupakan waktu yang cukup untuk seseorang dapat mempunyai sikap yang baik berdasarkan pengetahuan dan pengalaman yang ia miliki.

Sikap yang terbentuk dari dalam diri individu dapat terjadi karena beberapa hal. Salah satu hal tersebut adalah adanya informasi yang dapat meningkatkan intuisi sehingga bertambah pula ilmu yang didapatkan. Frekuensi informasi yang diperoleh responden berasal dari orang tua siswi, guru yang mengajar di sekolah, teman bermain, media elektronik seperti televisi dan media cetak misalnya majalah. Data primer yang didapat memaparkan 50 orang mendapatkan informasi seputar kesehatan dari orang tua mereka. Orang tua mempunyai kewajiban mutlak guna merawat dan melindungi supaya anak-anak senantiasa dalam keadaan sehat. Orang tua harus mampu memberikan pendidikan kesehatan kepada anak karena dapat digunakan untuk bersikap bijak khususnya dalam memutuskan sesuatu. Komunikasi antar ibu dan anak akan memberikan penambahan informasi yang lebih mudah dipahami (Yusuf, 2014). Penelitian Fajri dan Khairani (2010) menjelaskan bahwa komunikasi memberikan peran sebesar 30\% terkait kesehatan. Pendidikan kesehatan reproduksi penting disampaikan kepada remaja putri terlebih kebersihan genetalia ketika menstruasi. Orang tua diharapkan memiliki pengetahuan yang cermat dan benar agar dapat memberikan bahan ajar kepada anak tata cara dalam merawat dan menjaga organ direproduksi dengan baik. Perlu dilakukan sebuah upaya untuk menghindari terjadi nya gangguan di organ reproduksi.

Ardani pada tahun 2010 di SMPN 3 Pulau Rakyat Kabupaten Asahan melakukan penelitian yang sejalan dengan penelitian ini dan didapatkan hasil bahwa sebagian siswi memiliki sikap dalam kriteria baik terhadap perawatan mengenai kebersihan genetalia saat menstruasi. Hasil dari penelitian ini memiliki kesamaan karena banyak faktor.
Contoh ketersediaan informasi yang didapatkan dari orang tua ketika berada di rumah, teman satu sekolah maupun beberapa media lain. Memberikan suatu informasi kepada remaja putri khususnya mengenai higienitas individu saat menstruasi harus dapat disampaikan dengan jelas, lugas, dan tuntas. Jika penyampaian informasi tidak dapat diterima dan diingat dengan baik, maka akan terjadi dampak yang tidak diinginkan. Namun, bila remaja putri memperoleh penjelasan tersebut secara komprehensif, dapat dipastikan bahwa ia akan memiliki sikap yang baik pula. Pemaparan yang dilakukan Hidayat tahun 2009, seseorang akan mudah terpengaruh dengan hadirnya sebuah informasi. Tentunya, yang diharapkan ialah sebuah pengaruh baik. Pengaruh tersebut, akan dapat dicerna dengan seksama oleh remaja dan berimbas terhadap perilaku menjaga kebersihan diri sendiri ketika menstruasi.

Subjek penelitian yang memiliki sikap kategori cukup karena belum begitu menguasai mengenai materi personal hygiene ketika mengalami menstruasi. Demikian pula dengan responden dalam sikap kriteria yang kurang. Terkait masalah ini, disarankan untuk pengadaan kegiatan penyuluhan kelompok ataupun sosialisasi untuk remaja di sekolah yang dapat meningkatkan nilai pada sikap responden mengenai personal hygiene saat menstruasi agar secara keseluruhan memiliki sikap kriteria baik. Kegiatan tersebut bisa dilakukan melalui kerja sama lintas sektor dengan unit pelayanan kesehatan terdekat. Misalnya, tenaga kesehatan yang ada di Puskesmas setempat. Petugas kesehatan di Puskesmas dapat diajak berpartisipasi dengan aktif untuk memberikan ilmu terkait kesehatan reproduksi remaja. Penyebarluasan informasi yang akan dilaksanakan, memiliki efek yang positif bagi pengembangan pola pikir remaja. Remaja mendapatkan ilmu yang baik, maka akan berusaha untuk menerapkan pada dirinya. Jika ia sudah mampu, membiasakan hal tersebut, jadi tidak menutup kemungkinan untuk ia berbagi cerita maupun pengalaman yang dimiliki pada orang tua maupun rekannya. Selain itu, petugas kesehatan juga harus dapat mengarahkan dan mengimbau para 
remaja putri supaya terus merawat organ reproduksi pada saat hari-hari biasa dan terutama ketika menstruasi. Pemberian informasi ini memiliki makna yang penting untuk meningkatkan derajat kesehatan perempuan di masa yang akan datang. Penyuluhan akan berjalan lebih mantap apabila dibarengi pemberian media, seperti leaflet. Dengan adanya pembagian leaflet, kelak jika responden lupa mengenai beberapa hal terkait personal hygiene, maka dapat dibaca kembali.

Perilaku dalam aspek konatif atau penatalaksanaan mayoritas ialah kurang, yaitu 71 orang. Berdasarkan penelitian ini, lebih dari 50 persen, siswi melakukan praktik perawatan genetalia yang salah. Misal dalam sehari tidak mengganti pembalut kurang dari 4 kali dan menggunakan antiseptik dengan frekuensi yang sering untuk membersihkan dan merawat daerah sensitif di kewanitaan. Selain itu, pemilihan jenis bahan pembalut yang kurang benar guna mengatasi kebocoran ketika darah yang keluar pada saat menstruasi sedang banyak dan hanya keluar sedikit. Satu hari tidak mengganti celana dalam kurang dari 2 kali dan pada hari pertama menstruasi tidak mengganti pembalut dalam rentang waktu 1-2 jam. Hal lain adalah tidak mengganti pembalut sesudah buang air kecil (BAK), buang air besar (BAB), mandi serta melakukan cara cebok yang salah. Berbagai penatalaksanaan yang salah tersebut, jika dilakukan secara berkesinambungan, akan membahayakan diri remaja putri. Penyakit infeksi pada saluran reproduksi dapat meningkat dengan signifikan.

Faktor determinan yang dapat digunakan untuk mempengaruhi perilaku individu menurut Lawrence Green dikutip Notoatmodjo (2007) tersusun menjadi 3

Tabel 5. Distribusi Perilaku Aspek Konatif atau Tindakan tentang Personal Hygiene ketika Menstruasi di SMPN 2 Kras, Kabupaten Kediri

\begin{tabular}{lcr}
\hline \multicolumn{1}{c}{ Kriteria } & Frekuensi & \% \\
\hline Baik & 3 & 2,3 \\
Cukup & 56 & 43,1 \\
Kurang & 71 & 54,6 \\
\hline Total & $\mathbf{1 3 0}$ & $\mathbf{1 0 0}$ \\
\hline
\end{tabular}

bagian. Pertama, faktor predisposisi terdiri dari pengetahuan yang telah diperoleh seseorang, sikap yang dimiliki oleh individu, kepercayaan yang dianut setiap orang, keyakinan yang telah hidup di tubuh manusia bahkan sejak lahir, nilai yang berkembang pada diri dan masyarakat sekitar, dan lain sebagainya. Kedua, faktor pendukung meliputi lingkungan fisik misalnya adanya unit pelayanan kesehatan masyarakat terdekat seperti Puskesmas dan Ponkesdes, tersedianya obat untuk menyembuhkan pasien sakit, dan sarana prasarana contohnya alat kesehatan yang lengkap. Ketiga, faktor yang dapat mendorong terciptanya sikap maupun perilaku tenaga kesehatan seperti bidan, perawat, dan kesehatan masyarakat yang dapat dijadikan sebagai seorang panutan dan dapat melakukan perubahan perilaku dilingkungan sekitar.

Berdasar Tabel 5, diketahui bahwa 52 remaja (40\%) memperoleh sebuah informasi perihal higienitas perseorangan ketika menstruasi dari teman sebaya. Peran teman sebaya sebagai sumber informasi kesehatan reproduksi bukan referensi utama sebanyak $0,6 \%$ dan teman sebaya dapat mempengaruhi perilaku sehat maupun berisiko (Kusmiran dkk, 2006). Para remaja putri memiliki suatu anggapan bila dapat menceritakan segala masalah seputar reproduksi dengan lebih leluasa kepada teman yang seumuran dan tanpa merasakan suatu kecanggungan mengemukakan pelbagai kejadian yang pernah dan sedang dialami termasuk perihal kebersihan pada organ reproduksi yang dimiliki. Pesan yang diutarakan sahabat karib belum tentu mempunyai kebenaran yang hakiki. Siswi tidak mau melakukan klarifikasi dan mengajak berdiskusi, baik orang tua saat di rumah ataupun guru di sekolah. Kemudian, jauhnya akses menuju tempat pelayanan kesehatan juga menjadi poin penting yang menjadi kan siswi malas untuk menuju tempat tersebut sehingga remaja putri minim pengetahuan mengenai kesehatan reproduksi. Apabila hal tersebut terus berlanjut, dikhawatirkan terjadi perilaku yang lebih buruk sehingga berefek pada reproduksi.

Ada beberapa yang diwawancarai menjelaskan bahwa responden sudah menggunakan produk pembalut masa 
kini ketika menstruasi datang dan tidak mengenakan kain seperti zaman terdahulu. Pada saat seorang remaja putri memakai pembalut terbuat dari seutas kain, maka akan merasa khawatir jikalau ternyata kebersihan kurang terjamin. Pembalut tersebut kurang terjaga higienitas karena proses pengeringan yang tidak langsung di bawah terik sinar matahari, tidak bisa digunakan untuk menampung darah yang banyak saat menstruasi pada hari pertama, darah menstruasi kurang dapat diserap dengan baik, dan tidak nyaman untuk dikenakan pengguna. Pembalut kain dapat menyebabkan iritasi pada genetalia eksterna sehingga mikroba tumbuh dengan mudah serta dapat berkembang cepat dan vagina menjadi berbau tidak sedap sampai timbul keputihan yang tidak normal.

Subjek penelitian memaparkan jika tersedia pembalut di sekolah, namun tidak dibagikan secara cuma-cuma atau gratis melainkan diperjualbelikan di koperasi. Pernyataan diatas didukung argumen penelitian yang dilakukan oleh Rahmayanti tahun 2012 bahwa penyediaan pembalut di sarana pendidikan tidak memiliki keterkaitan bermakna terhadap perilaku dalam hygiene saat menstruasi pada remaja putri.

Dalam wawancara, responden juga menyatakan malas untuk berganti pembalut saat berada di sekolah karena kamar mandi dalam kondisi yang kotor, dan ketersediaan sumber air kurang memadai. Keadaan toilet yang tidak terawat memunculkan ketidaknyamanan tersendiri bagi pemakai, utamanya remaja putri yang hendak mengganti pembalut. Terlebih, kuantitas dari kamar mandi sekolah tidak sepadan dengan banyak siswa. Karena murid harus antre jika ingin buang air kecil, maka dapat buang air kecil sembarangan atau membuat para siswi menjadi enggan mengganti pembalut yang sudah penuh darah menstruasi sehingga ia menahannya sampai jam sekolah berakhir. Menurut UU Nomor 2 Tahun 2003, rasio ideal jumlah toilet perempuan 1:25 jumlah murid. Sedangkan, untuk lelaki adalah 1:40. Apabila seluruh 191 siswi menggunakan kamar mandi, setidaknya dibutuhkan 8 toilet. Frekuensi air bersih dibutuhkan untuk dapat menunjang kesehatan pada fungsi
Tabel 6. Distribusi Gambaran Perilaku Remaja Putri tentang personal hygiene saat Menstruasi di SMPN 2 Kras, Kabupaten Kediri.

\begin{tabular}{lcc}
\hline \multicolumn{1}{c}{ Kriteria } & Frekuensi & \% \\
\hline Baik & 61 & 47 \\
Cukup & 34 & 26 \\
Kurang & 35 & 27 \\
\hline Total & $\mathbf{1 3 0}$ & $\mathbf{1 0 0}$ \\
\hline
\end{tabular}

reproduksi seorang remaja putri. Hal tersebut terjadi karena ketika mendapati haid, siswi memerlukan cukup air guna membasuh dan membersihkan genetalia supaya dapat terhindar dari penyakit reproduksi.

Gambaran perilaku menunjukkan bahwa hampir dari 50 persen responden dalam kriteria baik. Terkait dengan hal ini, diketahui dari komponen pada pengetahuan bahwa semua siswi memiliki kognitif baik. Seorang remaja putri, banyak memperoleh pendidikan seputar kesehatan pada sistem reproduksi dari orang terdekat, yakni orang tua. Diketahui, orang tua berperan sangat besar dalam memberikan ilmu yang harus diterapkan oleh anak sejak dini dengan efektif. Subjek penelitian mempunyai sebuah pengalaman memadai untuk menanggulangi permasalahan terkait menstruasi yang dialami, yaitu didasarkan dengan tabel 1 bahwa waktu antara usia sekarang dengan usia pertama kami menstruasi adalah 2 tahun.

Pada Tabel 6, kriteria yang cukup dengan frekuensi 34 orang. Alasan tersebut berdasarkan analisa pada saat melakukan percakapan, responden menyatakan sudah tidak memakai pembalut yang terbuat dari kain, melainkan pembalut yang modern atau masa kini. Pembalut kain cukup diragukan mengenai kehigienitasannya dan tidak layak digunakan perempuan. Selain itu, pembalut dari sehelai kain juga tidak memiliki daya serap yang bagus serta kurang bisa menampung jumlah darah yang banyak keluar pada hari pertama saat menstruasi.

Ketika terjadi menstruasi, alat genetalia, baik eksternal maupun internal akan mengalami hipersensitif. Sangat ditakutkan, apabila seorang siswi masih mengenakan sebuah pembalut kain karena memiliki 
dampak yang buruk bagi fungsi saluran pada reproduksi. Misal mengalami gatal pada daerah vital sampai menderita infeksi.

Analisa penelitian dari Adelia tahun 2010, tidak ada hubungan yang signifikan terkait kesediaan pembalut di lingkungan sekolah dengan perilaku hygiene saat menstruasi. Hal ini sepadan dengan ungkapan responden bahwa ketersediaan pembalut di koperasi sekolah tidak membuat ia rajin mengganti pembalut. Selain itu, siswi juga menjelaskan bahwa merasa enggan ketika akan mengganti pembalut saat di sekolah karena ketersediaan air kurang mencukupi, kondisi toilet yang buruk dan sedikitnya jumlah dari kamar mandi.

Keterbatasan sumber air dapat berefek pada perilaku siswi yakni tidak rutin mengganti pembalut. Para remaja terutama putri, banyak memerlukan air guna membersihkan alat vital khususnya ketika mengalami menstruasi. Vagina harus dibasuh dengan air bersih dan mengalir, dimulai dari perineum hingga ke anus. Pelaksanaan tersebut bermaksud agar alat genetalia tetap terawat kebersihannya. Kurang bersih suatu kamar mandi, menyebabkan sering adanya keluhan dari remaja putri. Siswi kerap merasa risih berganti pembalut karena kamar mandi memiliki bau yang tidak enak. Keadaan demikian, membuat kenyamanan menjadi berkurang sehingga remaja putri memilih mengganti pembalut sepulang sekolah sesaat sesampai di rumah. Kurang mencukupinya frekuensi kamar mandi mengakibatkan remaja putri tidak ingin menunggu terlalu lama untuk mengantre. Terlebih pada saat jam istirahat. Karena biasanya, mayoritas responden ke toilet pada saat istirahat atau ketika pergantian jam pelajaran berikutnya.

Faktor yang dijelaskan tersebut, mempunyai pengaruh secara langsung terkait intensitas siswi dalam mengganti pembalut di sekolah. Padahal seperti yang diketahui, sebagian besar waktu pelajar lebih banyak dihabiskan saat berada di sekolah. Waktu yang dibutuhkan pelajar di sekolah adalah 6-10 jam. Sedangkan, batas normal waktu yang direkomendasikan untuk mengganti pembalut yang telah penuh dan lembab, yaitu 4 sampai 5 jam. Jika melakukan penggantian pembalut dengan melebihi waktu normal yang direkomendasikan, maka bakteri dengan mudah dapat masuk ke saluran reproduksi. Oleh sebab tersebut, peningkatan kejadian infeksi pada reproduksi akan terjadi .

Berdasar informasi bagian kesiswaan dan kurikulum bahwa pihak sekolah maupun pihak lain belum pernah melakukan kegiatan sosialisasi tentang perilaku yang sehat dalam menjaga organ reproduksi remaja. Penelitian yang dilakukan oleh Imarotul (2014) sejalan dengan temuan peneliti di lapangan, bahwa beberapa orang yang pernah mendapatkan suatu informasi terkait pendidikan kesehatan sebagian besar memiliki perilaku yang baik. Notoatmodjo tahun 2011 memberikan sebuah penjelasan yaitu informasi akan dapat meningkatkan suatu pengetahuan pada diri manusia. Pengetahuan akan menimbulkan sebuah kesadaran dan akhirnya menyebabkan seseorang melakukan perilaku tertentu. Dari dua keterangan tersebut, dapat diambil kesimpulan individu maupun sekelompok individu yang telah menerima ilmu khususnya mengenai kesehatan, maka pengetahuan yang diperoleh juga meningkat sehingga menimbulkan respons untuk berperilaku yang baik pula.

Pengetahuan mengenai masalah kesehatan pada reproduksi akan dapat memberikan pengaruh terhadap sikap individu dan perilaku dalam kehidupan seseorang. Jika pengetahuan tersebut baik, maka berpengaruh terhadap sikap yang dimiliki seseorang dan perilaku yang ditimbulkan juga baik, begitu pula sebaliknya. Ada suatu usaha guna meminimalisir infeksi genetalia, yakni melatih diri dengan rutin melakukan perilaku terkait hygiene individu yang benar. Akan tetapi, perilaku tersebut tidak akan terjadi begitu saja namun melewati beberapa proses yang panjang untuk mempelajari dan mempraktikkan agar individu mengerti dampak positif atau negatifnya. Perilaku manusia mengenai kesehatan yang menyangkut kebermanfaatan dalam proses pemeliharaan tubuh, makna merawat dan pentingnya kesehatan bagi kehidupan. Hal tersebut, secara tidak langsung maupun langsung akan memiliki pengaruh pada tingkat kepatuhan seorang individu terhadap 
masukan yang dilontarkan dan anjuran yang diberikan dari orang yang berpengalaman mengenai menstruasi, yaitu ibu, guru, dan petugas kesehatan setempat.

Beredarnya arus informasi yang kian hari semakin luas terutama dari media elektronik televisi dan media cetak berupa tabloid dapat mempengaruhi berkembangnya pola dalam proses berpikir pada remaja. Adanya sponsor mengenai produk pembersih untuk organ vital, membuat remaja kian ingin mengetahui dan melakukan percobaan untuk mengaplikasikan pada dirinya. Hal ini didukung dengan pesan dalam iklan tersebut dengan pemakaian teratur. Padahal kenyataannya, aktivitas seperti itu sangat berisiko untuk diterapkan dalam kehidupan sehari-hari. Lain hal lagi, kaum remaja putri telah terbiasa untuk mengganti pembalut yang dipakai tidak lebih dari 4 kali dalam satu hari dan membasuh genetalia dari arah belakang menuju ke depan. Pun mengoleskan larutan antiseptik yang tidak direkomendasikan guna kebersihan vagina, kurang tepat dalam memakai pembalut serta salah memilih bahan pembalut guna atasi masalah kebocoran ketika darah menstruasi yang keluar sedang sedikit atau banyak. Melakukan praktik perawatan daerah vagina yang tidak benar dengan seharian tidak salin celana dalam kurang dari 2 kali. Selain itu, pembalut diganti kurang dari 1 sampai 2 jam dan lebih dari 5 hingga 6 jam dan saat BAK, BAB serta mandi tidak mengganti pembalut sehingga menimbulkan suatu gangguan pada organ reproduksi. Lely tahun 2012 memaparkan bahwa perilaku personal hygiene buruk yang dilaksanakan oleh remaja akan mengakibatkan keputihan tidak normal kemudian terasa gatal pada genetalia eksterna, iritasi atau bahkan selulitis. Infeksi saluran kemih (ISK) pun dapat terjadi akibat dari cara cebok yang salah. Arah yang tidak tepat ketika membilas daerah perineal dan bentuk anatomi dari uretra yang pendek pada perempuan serta dekat dengan anal menyebabkan predisposisi terjadi nya infeksi.

Remaja seringkali tidak memiliki pertimbangan yang matang terkait baik dan buruk suatu informasi yang didapatkan. Tersebar luasnya media cetak dan media elektronik sangat mempermudah akses remaja untuk dapat mengetahui segala hal yang berhubungan dengan wanita, termasuk reproduksi. Adanya aktivitas tersebut, seharusnya mampu mengubah pola atau kerangka dalam berpikir agar menjadi semakin bagus. Perubahan pola pikir yang semakin kaya, dapat mempengaruhi individu dalam proses pengambilan keputusan. Sehingga kiranya remaja perlu memperbincangkan sebuah ilmu yang diperoleh dari berbagai media terkait tata cara perawatan kebersihan secara personal ketika haid kepada orang tua terutama Ibu. Karakter seorang Ibu sangat bermanfaat dalam memberikan arahan yang tepat terkait kesehatan pada reproduksi putri.

Kebersihan alat vital perlu sekali dilakukan karena ketika mengalami menstruasi pembuluh dalam darah pada rahim lebih mudah untuk terinfeksi. Maka dari itu, hygiene genetalia harus terus dijaga sebab bakteri begitu mudah untuk masuk serta sistem reproduksi terganggu. Penerapan sebuah perilaku terhadap kebersihan pada diri sendiri ketika menstruasi yang baik, dapat berasal dari adanya penambahan pada pengetahuan seseorang, sikap yang dimunculkan individu dan tindakan tepat sehingga tercapai organ reproduksi yang sehat.

\section{KESIMPULAN}

Berdasar hasil penelitian diatas, diperoleh kesimpulan antara lain: Pertama, perilaku pada remaja putri terkait personal hygiene saat menstruasi di komponen pengetahuan 100 persen dalam kriteria baik. Kedua, aspek sikap didapatkan bahwa 26 persen responden memiliki kategori baik. Ketiga, tingkatan tindakan diperoleh 27 persen dalam klasifikasi kurang, dan gambaran pada perilaku terkait remaja putri mengenai hal personal hygiene ketika mendapati menstruasi adalah 47 persen berkategori baik.

Dari kesimpulan diatas, dapat disarankan supaya pihak sekolah bekerja sama secara aktif dengan Puskesmas setempat. Kegiatan yang dapat dilaksanakan adalah sosialisasi, diskusi, tanya jawab terkait kesehatan reproduksi. Pembagian leaflet maupun penempelan poster di 
lingkungan sekolah dapat membantu menyadarkan siswi akan pentingnya perawatan diri terkait reproduksi. Selain itu, membentuk kelompok peduli kesehatan reproduksi yang melibatkan siswi. Dengan adanya beberapa kegiatan ini, diharapkan dapat menekan angka kejadian Infeksi Saluran Reproduksi pada remaja, khususnya remaja putri.

\section{DAFTAR PUSTAKA}

Adelia, Y. 2009. Gambaran Pengetahuan dan Sikap terhadap Perilaku Hygiene Menstruasi, Suatu Studi Kasus pada Siswi kelas 7 dan 8 SMPN 7 Depok. Skripsi, FKM UI Depok. 2009. http://lontar. ui.ac.id/file?file=digital/20293541-YYohana\%20Adelia.pdf. Diakses tanggal 3 Januari 2014, pukul 03.45 WIB.

Aisyaroh, N. 2010. Kesehatan Reproduksi Remaja. Skripsi. www.unissula.ac.id. Diakses tanggal 3 Januari 2014, pukul 02.00 WIB.

Ardani, M. 2010. Perilaku Remaja Putri dalam Perawatan Kebersihan Alat Kelamin pada Saat Menstruasi di SMPN 3 Pulau Rakyat Kabupaten Asahan Tahun 2010. Skripsi. http://MayaA2010.pdf. Diakses tanggal 3 Juli 2014, pukul 15.00 WIB.

Ariyani, I. 2009. Aspek Biopsikososial Hygiene Menstruasi Siswi SMP Pondok Pesantren Jakarta. Skripsi. FKMUI. http://lontar.ui.ac.id. Diakses tanggal 3 Januari 2014, pukul 03.15 WIB.

Ayu, F dan Maya, K. 2010. Hubungan antara Komunikasi Ibu-Anak dengan Kesiapan Menghadapi Menstruasi Pertama pada Siswi SMP Muhammadiyah Banda Aceh. Ejournal Undip. http://ejournal. undip.ac.id/index.php/psikologi/article/ download/288/5/2568. Diakses tanggal 5 Mei 2017 pukul 19.57 WIB.

Fitriyah, I. 2014. Gambaran Perilaku Higiene Menstruasi pada Remaja Putri di Sekolah Dasar Negeri di Wilayah Kerja Puskesmas Pisangan. Skripsi http:// ImarotulFitriyah-fkik.pdf. Diakses 3 Juli 2014, pukul 20.30 WIB.

Fuadbahsin. 2008. Tinjauan Umum Pengetahuan. http://click-gtg. com/2008/12/knowledge-apa-ukurannya. html. Diakses tanggal 5 Mei 2017 pukul 19.58 WIB.

Hidayat, A. 2009. Pengantar Ilmu Kesehatan Anak Untuk Pendidikan Kebidanan. Jakarta: Salemba Medika.

Keraf, S., dan Dua, M. 2011. Ilmu Pengetahuan. Yogyakarta: Kanisius.

Kusmiran, E., Wilopo, S., Paramastri, I. 2006. Hubungan Peran Teman Sebaya Sebagai Sumber Informasi Kesehatan Reproduksi dengan Sikap Remaja Mengenai Hubungan Seks Pra Nikah. http://stikesayani.ac.id/publikasi/ejournal/filesx/2006/200604/200604-003. pdf. Diakses tanggal 5 Mei 2017 pukul 20.14 WIB.

Leli, I. 2012. Gambaran Pengetahuan Remaja Putri Tentang Perineal Hygiene Di SMPIT As Salam Pasar Minggu. Skripsi http://digital_20301518-S42025IndidaLeliIndahF.pdf. Diakses tanggal 3 Juli 2014, pukul 20.34 WIB.

Manuaba, I. 2009. Memahami Kesehatan Reproduksi Wanita. Jakarta: EGC.

Mardani, S., Aris, S., Priyoto. 2010. Hubungan Pengetahuan Kesehatan Reproduksi Remaja Putri dengan Perilaku Personal Hygiene Menstruasi di Desa Kedung Kumpul Kecamatan Sarirejo Kabupaten Lamongan. Skripsi. http://7.pdf. Diakses tanggal 3 Juli 2014, pukul 14.45 WIB.

Maula, G. 2013. Reproduksi Saat Menstruasi Pada Remaja Putri Dengan Retardasi Mental. Skripsi http://GhinaMF2013.pdf. Diakses tanggal 3 Januari 2014, pukul 03.00 WIB.

Mubarak, W dan Chayatin, N. 2007. Kebutuhan Dasar Manusia Teori dan Aplikasi dalam Praktik. Jakarta: EGC.

Notoatmodjo, S. 2011. Kesehatan Masyarakat Ilmu \& Seni. Jakarta: Rineka Cipta.

Notoatmodjo, S. 2012. Metodologi Penelitian Kesehatan. Jakarta: Rineka Cipta.

Prawirohardjo, S. 2009. Ilmu Kebidanan. Jakarta: PT. BPSP.

Proverawati, A. 2009.Menarche Menstruasi Pertama Penuh Makna. Yogyakarta: Nuha Medika.

Qomariah, S. 2013. Hubungan Pengetahuan dan Sikap tentang Kebersihan Genetalia dengan Kejadian Fluor Albus 
(Keputihan) pada Remaja Putri. Skripsi. http://lppmunigresblog.files.wordpress. cm/2013/09/jurnal-keperawatan-samakovernya.pdf. Diakses tanggal 26 Februari 2014 jam 12.20 WIB.

Rahmatika, D. 2010. Pengaruh Pengetahuan dan Sikap tentang Personal Hygiene Menstruasi terhadap Tindakan Personal hygiene Remaja Putri Saat Menstruasi di SMK Negeri 8 Medan. Skripsi. http:// RahmawatiD2010.pdf. Diakses tanggal 3 Januari 2014, pukul 02.15 WIB.

Rahmayanti, N. 2012.Perilaku Perawatan Kebersihan Alat Reproduksi dalam Mencegah Kanker Serviks pada Siswi SMAN 9 Kebon Pala Jakarta Timur. Skripsi. http://lontar.ui.ac.id/ file? file $=$ digital $/ 20293541$ Novita $\% 20$ Rahmayanti.pdf Diakses tanggal 3 Januari 2014, pukul 01.45 WIB

Rakhmat, J. 2013. Psikologi Komunikasi. Bandung: PT. Rosdakarya.

Sari, I. 2012. Pengaruh Pendidikan Kesehatan tentang Menstruasi Terhadap Perubahan Perilaku Menstrual Hygiene Remaja Putri Untuk Pencegahan Infeksi Saluran Reproduksi (ISR). Skripsi. http://old.fk.ub. ac.id/Indah\%Puspita.pdf. Diakses tanggal 3 Januari 2014, pukul 02.20 WIB.
Sukarni, I. 2013. Buku Ajar Keperawatan Maternitas. Yogyakarta: Nuha Medika.

Tim Penulis Poltekkes Depkes Jakarta I. 2012. Kesehatan Remaja Problem dan Solusinya. Jakarta: Salemba Medika.

Wawan, A dan M, Dewi. 2011. Teori dan Pengukuran Pengetahuan, Sikap dan Perilaku Manusia. Yogyakarta: Nuha Medika.

Wulandari, R. 2012. Hubungan Pengetahuan Remaja Putri Usia 13-16 Tahun tentang Perawatan Alat Reproduksi Eksternal dengan PerilakuMerawatAlat Reproduksi Eksternal. Skripsi. Http://Www.Akbidpamenang. Ac.Id/Admin/Foto_Berita/23_Hubungan_ Pengetahuan_Remaja_Putri_Usia_13_16 Tahun_Tentang_Perawatan_A $\bar{l} a \bar{t}_{-}$ Reproduksi_Eksternal_Dengan_Perilaku_ Merawat_Alat_Reproduksi_Eksternal.Pdf. Diakses Tanggal 26 Februari 2014 Pukul 13.02 Wib.

Yusuf, Y., Kundre, R., Rompas, S. 2014. Hubungan Pengetahuan Menarche dengan Kesiapan Remaja Putri Menghadapi Menarche di SMP Negeri 3 Tidore Kepulauan. Jurnal. Https:// Ejournal.Unsrat.Ac.Id/Index.Php/Jkp/ Article/View/5272. Diakses Tanggal 5 Mei 2017, Pukul 20.00 Wib. 